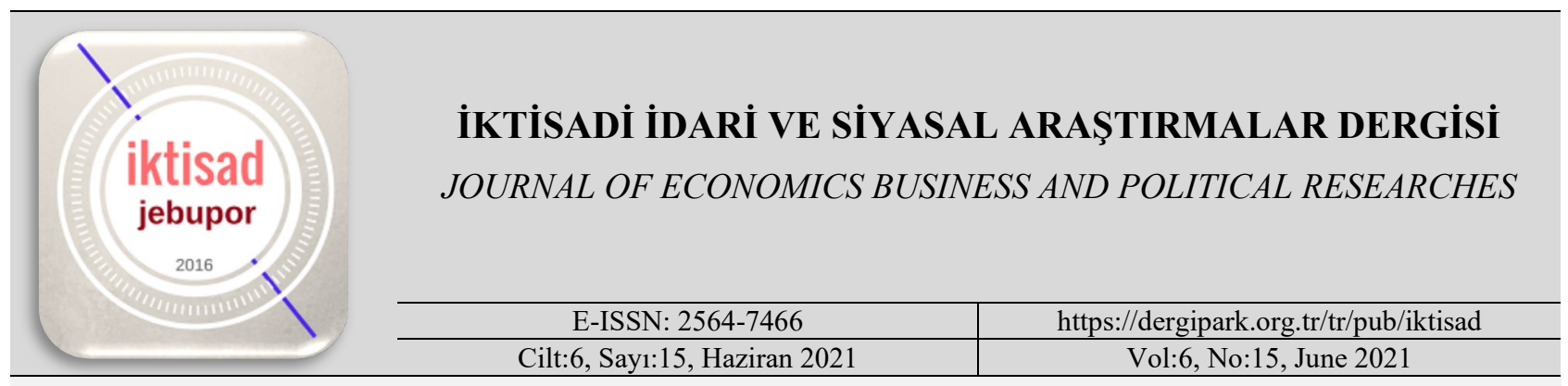

\title{
Örgütlerde Simbiyotik Yaşam: İşbirlikçiler, Sığıntılar ve Asalaklar
} Symbiotic Life in Organizations: Collaborators, Refugees and Parasites

Makale Bilgileri

Makale Türü:

Araştırma Makalesi

Geliş Tarihi: 06.01 .2021

Kabul Tarihi: 19.02.2021

(C)2021 IKTISAD

Tüm hakları saklıdır.

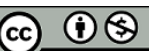

Disiplinler arası bir bakış açısıyla ele alınan bu çalışmanın amacı, simbiyotik ilişkilerin örgüt yaşamında varlığını incelemektir. Çalışmanın amacını gerçekleştirmek için simbiyotik yaşam mefhumu, örgüt yaşamına indirgenmiştir. Zira örgüt içinde de simbiyotik ilişkiler söz konusudur. Biyoloji kökenli bir kavram olan simbiyotik yaşamda, canlılar, birlikte ve birbirine bağıml olarak ortak yaşamaktadır. Bu türden bir ilişkide en dikkat çeken husus, canlıların birbirini yarar sağlama ya da zarar verme yönüyle etkilemeleridir. Yapılan inceleme sonucunda, örgüt yaşamında da bir başkası üzerinden geçinenler, bir başkasının gölgesine sığınanlar, kendini kullandıranlar ve tek taraflı ya da karşılıklı çıkar gözeterek iş ortaklığı gözetenler olduğu gözlemlenmiştir. Neticede, örgütlerde simbiyotik ilişki içerisinde hareket eden üç farklı çalışan tipi ve davranışı tanımlanmıştır: İ̧̧birlikçiler, sığıntılar ve asalaklar.

Anahtar Kelimeler: Simbiyotik yaşam, simbiyotik ilişki, ortak yaşam, örgüt, işletme.

\section{Article Info}

Paper Type:

Research Paper

Received:

06.01.2021

\section{Accepted:}

19.02.2021

C2021 JEBUPOR All rights reserved.

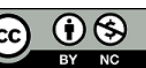

\begin{abstract}
The aim of this study, which is handled with an interdisciplinary perspective, is to examine the existence of symbiotic relationships in organizational life. In order to realize the aim of the study, the concept of symbiotic life has been reduced to organizational life. Because there are symbiotic relationships within the organization. In symbiotic life, which is a concept based on biology, living things live together and depend on each other. The most striking point in this type of relationship is that living things affect each other to benefit or harm. As a result of the examination, it was determined that there are people who live on someone else in the life of the organization. In addition, the presence of those who took shelter in someone else's shadow was also observed. Again, there are those who pursue business partnerships on a unilateral or mutual interest. As a result, three different types of workers and behaviors have been identified in organizations acting in symbiotic relationship: collaborators, refugees and parasites.
\end{abstract}

Keywords: Symbiotic life, symbiotic relationship, symbiosis, organization, business.

Atıf/ to Cite (APA): Mücevher, M.H. (2021). Örgütlerde simbiyotik yaşam: işbirlikçiler, sığıntılar ve asalaklar. İktisadi İdari ve Siyasal Araştırmalar Dergisi, 6(15), 172-184

*ORCiD Öğr. Gör. Dr., Isparta Uygulamalı Bilimler Üniversitesi, mhmucevher@gmail.com 


\section{Extended Abstract}

\section{Introduction and Research Questions \& Purpose:}

Employees collaborate and establish various relationships in order to continue their activities, cope with variable conditions and complete each other's missing parts. Employees increase their skills and maintain their continuity through these relationships that aim to achieve mutual benefit. Inspired by the concept of biological originated symbiosis, we can name such relationships as symbiotic relationships. The aim of this study is to examine whether symbiotic relationships exist in organizational life.

\section{Literature Review:}

The essence of symbiotic relationships is the survival efforts of organisms. Symbiotic relationships generally aim to achieve mutual benefit. Symbiotic relationships are two or more people taking action towards a common or specific goal.

By reducing the concept of symbiosis to the organization, it can be mentioned about symbiotic relations as well as industrial (organizational) symbiosis in terms of relations between organizations. Industrial symbiosis is when organizations join forces to adapt to changing environmental conditions, gain competitive advantage, reduce costs, improve their skills and complete their deficiencies. One of the concepts that emerged with the handling of the concept of symbiosis with different disciplines is symbiotic leadership. The symbiotic leadership style acts on the principle of mutual benefit for the employee, leader and organization. Symbiotic leadership is based on the principle of motivating employees in order to increase their productivity and performance and increasing the success of the organization. Symbiotic leaders create flexible and conducive environments for their followers. In addition, symbiotic leaders give employees the opportunity to reveal their potential and innovative structures. For this, symbiotic leaders use mechanisms such as development, participation, trust and reward. As can be seen, the concept of symbiotic life (relationship) is discussed in different ways in the business and management literature. However, in this study, symbiotic relationships within the organization were examined. In this context, the existence of symbiotic life in organizational life was discussed by examining symbiotic relationships/behaviors such as those who act in a mutual interest relationship (collaborators), those who live in the shadow of someone else (refugees) and those who live on someone else's back (parasites).

\section{Methodology:}

The method preferred in the study is case presentation. In this study, a suggestion is made that symbiotic relationships are also established in organizations. For this purpose, symbiotic relationship types originating from biology were examined first. Later, the symbiotic species determined as a result of this examination, reduced the life of the organization. Thus, a definition has been made about employee types and behaviors that show symbiotic relationships in organizational life.

\section{Results and Conclusions:}

As a result of this study, three different types and behaviors of employees who act in symbiotic relationships in organizations are defined. These employee types, collaborators, refugees and parasites. Collaborators are aware of their shortcomings. For this reason, collaborators join forces and share interests for jobs that they cannot tackle alone. For this, collaborators use ways such as synergy, teamwork, partnership, alliance, solidarity, agreement, compromise and compromise.

Refugees are aware of their incompetence, lack of self-esteem, incapacity and inadequacy. Also, refugees know that they cannot exist without someone else. Refugee types are free rider, freeloader, sidekick, clown, smarmy, greaser, yes man, ready and engaged individuals. Refuges try to survive in these ways. 


\section{GİRIŞ}

Çalışanlar, diğer çalışanlarla çeşitli nedenlerle farklı biçimlerde ilişkiler kurmaktadır. Nedeni şu ki, faaliyetleri sürdürmek, değişken şartlar ile baş edebilmek ve birbirlerinin eksik taraflarını tamamlayabilmek için birbiriyle iş ve güç birliği yapmaları, iletişim ve ilişki içerinde olmaları gerekir. Karşılıklı yarar elde etme amacı güden bu ilişkiler sayesinde çalışanlar, becerilerini arttırmakta ve devamlılıklarını sağlamaktadırlar.

Örgütlerde meydana gelen bu tarz ilişkileri, biyolojik kökenli simbiyoz kavramından esinlenerek simbiyotik ilişkiler olarak nitelendirmek mümkündür. Simbiyotik ilişkilerin özünde, organizmaların (örgüte indirgersek çalışanların) varlıklarını sürdürme uğraşları vardır. Genel olarak karşı1ıklı yarar elde etme amacı taşıyan simbiyotik ilişsiler, iki ya da daha fazla kişinin ortak ya da belirli bir hedef yönünde bir eyleme girişmeleridir.

Simbiyoz kavramının örgüt içine indirgenmesiyle simbiyotik ilişkilerden söz edilebileceği gibi örgütler arası ilişkileri ifade eder şekilde endüstriyel (organizasyonel) simbiyozdan da bahsedilebilir. Endüstriyel simbiyoz, organizasyonların, değişken çevre koşullarına uyum sağlamak, rekabet avantajı elde etmek, maliyetlerini düşürmek, yeteneklerini geliştirmek ve eksiklerini tamamlamak gibi amaçlarla güç birliği yapmalarıdır.

Simbiyoz kavramının farklı disiplinlerle ele alınmasıyla ortaya çıkan kavramlardan bir tanesi de simbiyotik liderliktir. Çalışan, lider ve örgüt açısından karşılıklı yarar ilkesiyle hareket eden simbiyotik liderlik tarzı, çalışanların verimlilik ve performanslarını arttırmak amacıyla motive edilmesi, örgütün başarısının arttırılması esasına dayanır. Simbiyotik liderler, takipçileri için esnek ve elverişli ortamlar yaratarak potansiyellerini ve yenilikçi yapılarını açığa çıkarma firsatı tanırlar (Köksal, 2011; Zaccaro ve Horn, 2003). Bunu sağlamak adına gelişim, katılım, güven ve ödül gibi mekanizmalarını kullanırlar.

Görüldüğü gibi simbiyotik yaşam (ilişki) kavramı, işletme ve yönetim literatüründe farklı şekillerde ele alınmaktadır (Çolakoğlu, 2019; Köksal, 2011; Zaccaro ve Horn, 2003). Lakin bu çalışmada, örgüt içerisindeki simbiyotik ilişkilere değinilecektir. Bu kapsamda karşılıklı çıkar ilişkisi içerisinde hareket etme (işbirlikçilik), başkasının gölgesi (sığıntıcılık) ya da sırtından geçinme (asalaklık) gibi simbiyotik özellikler gösteren ilişkiler/davranışlar incelenerek simbiyotik yaşamın örgüt yaşamında varlığı ve yansımaları tartışılacaktır.

$\mathrm{Bu}$ uğraş, örgüt içerisinde simbiyotik yaşam sonucu ortaya çıkan çalışan ilişkilerinin/davranışlarının tanımlanmasına katkı sağlayacaktır. Bunun bilinmesi, örgütlerdeki simbiyotik davranışların sebeplerinin bilinmesine, bu tür davranışların önceden kestirilmesine ve kontrol edilmesine zemin hazırlayacaktır. Bu da çalışanların daha bilinçli ve etkin yönetimi ve yönlendirilmesi konusunda örgüte, yönetsel anlamda yarar sunacaktır.

Bu saik ile ele alınan çalışmada, öncelikle simbiyoz ve simbiyotik ilişki (yaşam) kavramlarıyla ilgili özet bilgilere değinilecek, daha sonra örgütlerde simbiyotik yaşamın varlığ kısımda, simbiyotik ilişki içerisinde olan işbirlikçi, sı ğıntı ve asalak çalışan tipleri ve davranışlarıyla ile ilgili ayrıntılı önermelerde bulunulmaya çalışılacaktır.

\section{SIMBIYYOZ, SIMMBIYOTIKK YAȘAM KAVRAMLARI}

Fransızca symbiose, "Birlikte ve birbirine bağımlı olarak yaşama.", sözcüğünden alıntı (Nişanyan, 2020) olan simbiyoz kavramının Türkçe karşılığı olarak "Ortak yaşam” kavramı (TÜBA, 2020; Özyiğitoğlu, 2017) kullanılmaktadır. Birden fazla türün bir arada yaşaması anlamında, yaşam ortaklığını tarif eden (Özyiğitoğlu, 2017) ve biyoloji kökenli bir terim olan simbiyoz, farklı canlı gruplarının bir arada veya bir türün diğer tür içerisinde ortaklaşa olarak birbirleri lehine ve yakın etkileşim halinde yaşamaları (TÜBA, 2020) anlamına gelmektedir. 
Simbiyoz ya fiziksel olarak birbirine bağlı ya da biri diğerinin içinde yaşayan organizmaların durumunu ifade eder. Simbiyoz, iki ya da daha fazla canlı arasındaki ilişki ile ilgilendiği için bu canlılar arasındaki ilişki, "Simbiyotik ilişkiler" olarak ifade edilir. Bu ilişkiyi inceleyen bilim, "Symbiologi"; canlılardan her biri ise "Symbiont" olarak isimlendirilir.

Simbiyotik ilişkiler, iki canlı arasındaki ilişkiye göre farklı isimler alabilir. Simbiyotik ilişkilerde, ortak yaşam aracılığıyla organizmalardan biri diğerine yarar sağlayarak varlığını sürdürme olasılığını arttırma çabası içerisine girer (Doğan, 1996). Simbiyotik ilişkinin kilit noktası, her organizmanın diğerinin bağlantılı varoluşu nedeniyle gelişmesi (Zaccaro ve Horn, 2003), birlikte yaşama ve karşılıklı yarar sağlamadır (Smith, 1997).

Simbiyoz kavramı psikoloji ve işletme literatüründe de kullanılmaktadır. Simbiyoz, psikoloji disiplininde, hastalık derecesinde bir başkasına bağlılık olarak tanımlanırken; işletme literatüründe, endüstriyel simbiyoz olarak kullanılmaktadır. Endüstriyel (organizasyonel) simbiyoz, birbirlerinden bağımsız şekilde faaliyet gösteren iki ya da daha fazla işletmenin bir araya gelerek performans ve rekabet gücünü arttırmak için uzun vadeli ortaklıklar kurması ve dayanışma içinde hareket etmesi şeklinde tanımlanmaktadır (Çolakoğlu, 2019).

Simbiyoz kavramı, bu kullanımlarından başka anlamlarda da anlaşılabilmektedir. Birlikte yaşam, bazen çok kültürlü ve ortak yaşam alanlarına, ortak yaşam kültürü ve felsefesine işaret eder şekilde farklı kültürel kimliklerle birlikte yaşamı ve ortak sosyal yaşamı (Yeşilmen, 2019; Ünal, 2017; Bayraktar, 2014) ifade etmek için de kullanılmaktadır.

\section{SIMBIYYOTIK İLISSKKI TÜRLERİ}

Simbiyotik yaşamda; mutvalizm, kommensalizm, parazitizm, nötralizm ve amensalizm olmak üzere çeşitli ilişki türleri vardır. Mutvalizmde, karşılıklı çıkar ve yarar ilişkisi mevcuttur. Bu sebeple taraflar, işbirliği içinde yaşar, yardımlaşır. Aralarında bir ortaklık var gibidir ve bundan dolayı taraflardan her biri ortak (mutual) olarak nitelendirilir. Bu simbiyotik ilişki türünde zorunlu işbirliği olduğu gibi zorunlu olmayanları da vardır (Zeyrek, 2020; Keeton ve Gould, 2003).

Kommensalizm türünde ise taraflardan birisi yarar sağlarken diğeri bu ilişkiden etkilenmez. $\mathrm{Bu}$ ilişki türü, tabiri caiz ise sığıntı bir insanın bir başka birine sofra arkadaşlığı yapmasına benzetilebilir. Sığıntı olarak isimlendirebileceğimiz canlının (symbiont) üzerinde ya da içinde yaşadığı organizmaya hiçbir zararı ya da yararı yoktur. Bu iki canlı arasında metabolik bir bağ da yoktur ve aralarında ilişki gevşek bir yapıdadır. Bu ilişkide symbiont, sığındığı canlıdan beslenme, taşınma ve barınma gibi konularda yarar sağlar (Keeton ve Gould, 2003; Zeyrek, 2020).

Parazitizm ilişki biçiminde ise taraflardan birisi yarar sağlarken diğeri zarar görür. Yarar sağlayan canlı, parazit; zarar gören canlı ise konak olarak adlandırılır. Bu ilişkide parazit, konağa bağımlı olarak yaşar ve konağa göre daha küçük ve güçsüzdür. Ancak parazitler, yine de konağa zarar verir, hasta eder, sömürür, süründürür hatta ölümüne sebep olabilir. Parazitleri, yarı, tam, iç ve dış parazitler diye dörde ayırmak mümkündür. Nötralizm türünde, her iki canlı türü de birbirinden olumlu ya da olumsuz etkilenmez. Son olarak amensalizmde ise taraflardan birisi zarar görürken diğeri etkilenmez. Bu ilişki türlerinde ilk üç ilişki türü daha çok öne çıkar ve simbiyotik yaşam bu üçü arasında gidip gelir. Aralarında kesin bir sınır yoktur (Zeyrek, 2020).

\section{4. ÖRGÜTLERDE SIMBIYOTIK YAŞAM/İLIŞKILER}

İşletme ve yönetim alanı için simbiyoz ya da simbiyotik yaşam (ilişki) kavramının oldukça sınırlı bir kullanımının olduğu görülmektedir. Ancak simbiyoz teriminin işletme ve yönetim yazınına uyarlanmasıyla birlikte organizasyonlar arası simbiyotik ilişkilerden (endüstriyel simbiyoz) söz edilmeye başlanmıştır. Organizasyonlar, simbiyotik bir ilişki kurarak birbirlerinden karşılıklı fayda 
sağlamakta ve bu sayede rekabet üstünlüğü elde etmeye çalışmaktadırlar (Köksal, 2011). Değişken ve karmaşık çevre şartlarına karşı meydan okumak ya da uyum sağlayabilmek, yeteneklerini birleştirmek, maliyetlerini düşürmek, teknolojilerini arttırmak gibi nedenlerle örgütler, birbirlerinin zayıf taraflarını tamamlamak ve güç birliği yapmak için bir araya gelmektedirler. Örgütleri, bu iş birliğine iten neden, karşılıklı fayda elde etme, varlıklarını sürdürme ve rekabet avantajı edinme çabasıdır. Örgütler arası bu tür işbirlikleri, simbiyotik ilişki olarak nitelendirmek mümkündür.

Simbiyotik ilişki mefhumu ile birlikte bir de "simbiyotik liderlik" diye, yeni bir liderlik tarzından bahsedilmektedir. Zaccaro ve Horn (2003), mevcut liderlik teorilerinin, uygulayıcılara örgütsel liderlikte ortaya çıkan sorunların çözümüne dair yardımcı olamadığını öne sürerek liderlik teorileri ile liderlik pratikleri arasında etkili bir simbiyozdan (entegrasyondan) söz ederek bir öneride bulunmuştur: Leadership theory and practice symbiosis (LTPS). Bu öneriye göre, liderlik teorisi ve uygulamalarının her biri, diğer teori ve uygulamalara daha yakın bağlandıklarında ve birlikte kullanıldıklarında, daha fazla canlılık ve yaşama gücü sergileyebileceklerdir.

Simbiyotik liderlik, farklı açıdan da ele alınmaktadır. Bu farklı bakış açısına göre simbiyotik liderlik, örgüt üyelerinin örgüte olan katkılarını arttırma amacı taşıyan ve kendilerini göstermelerine firsat veren ve motive eden bir liderlik tarzıdır (Köksal, 2011).

Simbiyoz kavramının işletme ve yönetim literatüründeki yerine değindikten sonra biyoloji biliminin ortaya koyduğu simbiyotik ilişki türlerinden yola çırak örgütlerde simbiyotik ilişki içinde yaşayan üç tür çalışan tipi ve davranışından bahsedilebilir: Işbirlikçiler, sığıntılar ve asalaklar.

Örgütlerde bazı çalışanlar, sinerji, takım çalışması, yardımlaşma, uzlaşma ve dayanışma gibi işbirlikçi davranışlar sergilemektedir. Çalışanlar arasındaki bu tür davranış ve ilişkiler, simbiyotik ilişki türlerinden, karşılıklı fayda ve menfaati gözettikleri için yardımlaşma ve ortaklık içerinde hareket eden "mutvalizm"e benzetilmiş ve "İşbirlikçiler" olarak tanımlanmıştır.

Örgütler yaşamında, bir başkasına angaje davranmak, dalkavukluk, yalakalık, yağcılık yapmak, tasdikçi, hazırcı ve bedavacı davranmak, acizlik göstermek gibi davranışlar sergileyerek bir başkasının gölgesine sığınan tipler ve davranışlar da vardır. Bu tür kişiler ve ilişkiler, simbiyotik ilişki çeşitlerinden bir taraf fayda sağlarken diğer tarafın olumlu ya da olumsuz olarak etkilenmediği, tek taraflı bir birliktelik olan "kommensalizm" içerisinde değerlendirilerek "Sığıntılar" olarak sinıflandırılmıştır.

Son olarak üretmeyip tüketmek, başkasının sırtından geçinmek, tembellik etmek, kaytarmak, aylaklık etmek gibi davranışlar içerisinde bulunan örgüt çalışanları ve davranışları, taraflardan birinin yarar sağlarken diğerinin zarar gördüğü simbiyotik ilişki türü olan "parasitizm”e benzetilerek "Asalaklar" olarak tasnif edilmiştir.

Örgüt yaşamında simbiyotik ilişki türlerinden bu üç ilişki türü daha çok öne çıkmaktadır. Diğer simbiyolojik ilişki türleri olan nötralizm ve amensalizm içerisinde değerlendirilebilecek çalışan tipleri ve davranışları, illaki olmakla birlikte çok fazla gözlemlenemediği için sadece bu üç çalışan tipi ve davranışları üzerinde durulmuştur. Bu noktadan sonra, simbiyotik ilişki içerisinde varlıklarını sürdüren bu çalışan türleri, sırasıyla ele alınacaktır.

\section{1. İşbirlikçiler}

Bireyler, tüm ihtiyaçlarını tek başlarına karşılamaya yetecek fiziksel ya da psikolojik yeterliliğe sahip olmadığı için birbiriyle işbirliği yaparlar (Alıç, 1995). Örgüt çalışanları da tek başlarına yapamayacakları görevler ve işler için bir araya gelmekte ve güçlerini birleştirmektedirler. "Yalnız taş duvar olmaz." ve "Baş başa vermeyince taş yerinden kalkmaz.” özlü sözleriyle günlük hayatta çokça üzerinde durduğumuz işbirliği, bir işin farklı kişilerce yapılması, çıkarları ve amaçları aynı olanların meydana getirdiği çalışma ortaklığı, aynı amaç ve iş için birlikte çalışmak (TDK, 2020; 
Kubbealtı, 2020) demektir. İşbirliği içerisinde olan kişiyi işaret eden işbirlikçi ise "Herhangi bir alanda çıkar sağlama amacını güden kimse" (TDK, 2020) anlamına gelmektedir.

Çalışanlar arasındaki işbirliği, üretim faktörlerinin bir araya getirilmesi, dönüştürülmesi ve çıktı olarak sunulması, sorunların çözümü, iş ve görevlerin yürütülmesi gibi örgütsel faaliyetlerin rekabetçi avantaj sağlayacak şekilde yürütülmesi açılarından önemlidir (Hardy, Phillips ve Lawrence, 2003). $\mathrm{Bu}$ anlamda, örgütlerde ortaya çıkan işbirliği ve işbirlikçi çalışan davranışları, simbiyotik ilişki türleri içerisinde yer alan, karşılıklı fayda ve menfaati gözettikleri için işbirliği, yardımlaşma ve ortaklık içerinde hareket eden mutvalizme benzetilebilir.

Örgütlerdeki simbiyotik yaşamın bir yansıması olan işbirlikçiler, ortak ya da şahsi amaçları gerçekleştirmek için menfaat ve yarar ilişkisi içerinde olduklarından, örgüt içerisinde; sinerji oluşturma, takım halinde çalışma, ortaklık, konsersiyum ve ittifak kurma, yardımlaşma, anlaşma, bağdaşma, uzlaşma, dayanışma ve kyosei oluşturma gibi davranışlar sergileyebilmektedir.

Artı güç, görevdaşlık, bir işi yapmak ve sonuçlandırmak için varılan ortak istek, güç (TDK, 2020), birlikte çalışma, güçlerini birleştirme (Nişanyan, 2020) anlamlarına gelen sinerjinin özünde işbirliği vardır. Türkçemizde de "Birlikten kuvvet doğar." atasözü ile kendine karşılık bulan sinerji terimi, birden fazla unsurun bir arada oluşturdukları etkinin ayrı ayrı oluşturacakları etkilerin toplamından daha fazla olması (Lai, 2000) anlamına gelmektedir. Yani sinerji, birliktelik sayesinde iki ile ikinin toplamının dörtten fazla çıkmasını sağlayan kuvvettir. Sinerji üzerine kurulu bir işbirliğinde, ortak bir hedef için tarafların bir araya gelerek gayret göstermeleri amaçlandığ 1 için bu uğraş, simbiyotik ilişki içerisinde değerlendirilebilir. Zira sinerjide, karşılıklı faydaya ve ortak bir amacı gerçekleştirmeye dayalı eylem birlikteliği vardır.

Örgütlerde işbirliğine dayalı simbiyotik ilişkiler, bazen de karşımıza takım çalışması şeklinde çıkar. Sürekliliğini korumak ve rekabet edebilecek bir konumda olmak isteyen her çalışanın bireysel olarak eksik kaldığı yönler olabilir. Bunu aşmak için bireyler tecrübe, bilgi, uzmanlık, beceri ve yetkinliklerini birleştirerek takımlar oluştururlar. Takımlar, her bireyin katkılarının toplamından daha fazla ve kapsamlı bir başarım ortaya koymak (Robbins ve Judge, 2009), farklı uzmanlık ve yeteneklerinin bir araya getirerek bir misyonu başarmak için bir araya gelirler (Donnolen, 1998). Takım çalışması şeklinde hareket eden çalışanlar, ortak bir hedefe varmak için bir araya gelerek bilgi, beceri ve deneyimlerini uyumlu bir şekilde birleştirirler. Takım çalışmasında, ortak amaca ulaşmak için gösterilen uğraşların toplamının oluşturacağı etki önemlidir. Diğer adıyla ekip çalışmasında önemli olan nokta, bütün ekibin tek bir kişi (ruh) olarak hareket etmeleri ve takım ruhunu ortaya çıkarmalarıdır.

Karşılıklı çıkar ve yarar ilişkisi kurmak isteyen örgüt çalışanlarının yaptığı bir diğer işbirliğine dayalı simbiyotik ilişki çeşidi, kyosei ya da diğer ismiyle kaishadır. Kyosei, ortak bir yarar için birlikte çalışmak ve yaşamak anlamında kullanılan Japonca bir kavramdır. Kyosei felsefesine göre hareket eden çalışanlar, aile yaşamına benzer bir dayanışma ve yardımlaşma içerisinde hareket ederler.

Her iki organizmanın da birbirlerinin başarısı için önemli birer fonksiyona sahip olduğundan hareketle simbiyotik bir ilişki, bazen de iki organizmanın doğal yaşamlarının bir parçası olarak birbirlerine güvenmeleri sonucu ortaya çıkar (Köksal, 2011). Bu yönüyle örgüt içerisindeki yardımlaşma, paylaşma ve dayanışma davranışları, işbirliği esaslı simbiyotik ilişkiler içerisinde değerlendirilebilir. Paylaşma davranışı gösteren çalışanlar, işleri, görevleri ve karşılığında elde ettikleri edinimleri aralarında bölüşür, pay eder ve üleşir. Dayanışma sergileyen çalışanlar ise bir amacı gerçekleştirmek için duygu, düşünce ve çıkar birliği göstererek birbirini kollar, birbirine dayanır, destek olur, birlik içinde olup birbirinden kuvvet alır.

Diğer taraftan örgüt çalışanlarının simbiyotik ilişki içerisinde olup işbirliği yapmaları; anlaşma (uyuşma, bağdaşma) ve uzlaşmalarına da bağlıdır. Ortak bir amacı gerçekleştirme için çalışanlar; düşünce, duygu, amaç bakımından birleşmek, birbirinin maksadını anlamak, duygu ve düşüncelerini 
birbirine uydurmak, aynı fikir üzerinde karar kılmak, mutabakata varmak, anlaşma yapmak, ittifak etmek zorundadırlar. Bunun yanında çalışanların uzlaşması da gerekir. Yani menfaat birlikteliği için aralarındaki düşünce ve çıkar ayrılığını, uyuşmazlıkları, karşılıklı ödünlerle kaldırarak karşılıklı anlaşmak ve uyuşmak gerekliliği ile hareket ederler. İç içe geçmiş bu kavramların özünde bağdaşma, uyum sağlama, uyum içerisinde olma, iyi geçinme ve arkadaşlık vardır.

Görüldüğü gibi örgütlerde ortaya çıkan işbirliği ve işbirlikçi davranışlar, simbiyotik bir ilişki içerisinde değerlendirilebilir. İşbirlikçi çalışanlar, her ne kadar eylemlerinin özünde bireysel menfaat elde etme kaygısı olsa da kazan kazan mantığı ile hareket ederler. Çünkü amaçları, devamlılık ve rekabetçi üstünlüklerini sürdürmektir. Bunu sağlamak için diğer çalışanlar ile işbirliği yaparlar. Bu ilişkiler sinerji, takım çalışması, kyosei, yardımlaşma, dayanışma, paylaşma, anlaşma gibi farklı şekillerde gerçekleşse de hepsinin esası, karşılıklı yarar ve menfaat sağlamaktır.

Örgütler, bireysel menfaat için karşılıklı menfaati göze alan işbirlikçi çalışanlardan, katılım, iç girişimcilik, yenilik, yaratıcılık, çatışma yönetimi gibi konularda yararlanabilir. Zira bu tür çalışanlar, rekabetçi üstünlüklerini korumak ve sürdürülebilir olmak için girişkenlik, eylem odaklılık, üretkenlik, çalışkanlık, yenilik, yaratıcılık gibi davranışlar sergilemek isterler.

\subsection{Sı̆̆ıntılar}

Sığıntı çalışan tipleri ve davranışları, simbiyotik ilişki türlerinden bir taraf fayda sağlarken diğer tarafın olumlu ya da olumsuz olarak etkilenmediği, tek taraflı bir birliktelik olan kommensalizm içerisinde değerlendirilebilir. Sığıntı, "Bulunduğu yerde kalması istenmeyen, varlığı gereksiz görülen kimse.” (TDK, 2020) demektir. Sığıntı çalışanların en büyük özelliği bir başkasına bağımlı ve muhtaç olmalarıdır. Sığıntı tipler, sığındıkları kişiler sayesinde (gölgesinde) varlıklarını sürdürürler. Bunun yanında bu kişilerin özgüvensiz ve edilgen kişilik yapıları, utangaç, korkak ve çekingen kişilik özellikleri öne çıkmaktadır. Sığıntı çalışanlar, yetenek, yetkinlik, bilgi, uzmanlık ve deneyim bakımından sığ oldukları gibi özerk bireyler de değillerdir.

$\mathrm{Bu}$ noktada sığıntı psikolojisinden bahsetmek yerinde olacaktır. Çünkü sı̆̆ıntı şeklinde simbiyotik bir ilişki içerisinde bulunan taraf, sığıntı psikolojisi içerisinde hareket etmektedir. Bu tarz bir ilişkide, çocuk ile anne ya da hasta ile bakıcı arasında ortaya çıkan bir ilişki görülür. Bu psikolojiye sahip kişiler, sığındıkları kişilere aşırı derece bağlı ve bağımlıdırlar. Barınma, beslenme gibi yönlerden sığındıkları kişilere muhtaç oldukları için kendilerini çaresiz, özgüvensiz ve yetersiz hissederler. Bu sebeple sığıntı psikolojisi içerisine girerler.

Örgütlerde simbiyotik ilişki içinde yaşayan türlerden olan sı̆̆ıntılara, Barner (1994)'ın personel güçlendirme kavramı için geliştirdiği "güçlendirme" ve "yapılabilir hale getirme" olarak iki boyutlu bir matriste, "değişmez sığıntılar" olarak rastlanmıştır. Matrisin boyutlarından birisi olan güçlendirme, çalışanın sahip olduğu örgütsel ve bireysel gücü temsil ederken diğer boyut olan yapabilir hale getirme, çalışanın sahip olduğu güç ve otorite derecesini temsil etmektedir. Bu iki boyutlu matrise göre "değişmez sığıntılar", otorite ve gücü yönetme becerisi olmayan, yetenek, beceri ve yetkinlikleri yetersiz olan ve mücadeleden kaçınan çalışanları ifade etmektedir (Torun, 2016; Genç, 2017).

Dalkavukluk, yalakalık, angajelik, yağcılık, şaklabanlık, tasdikçilik, hazırcılık, yancılık, bedavacılık, beleşçilik, beceriksizlik, vasıfsızlık, acizlik ve özgüvensizlik göstermek gibi davranışlar sergileyerek bir başkasının gölgesine sığınan tipler ve davranışları, örgüt yaşamında varlığı görülen sığıntılara örnek olarak gösterilebilir.

Örgüt içerisinde, sığıntı şeklinde ortaya çıkan simbiyotik ilişkilerin en önde gelen yansımaları olarak dalkavukluk (yağcılık, yalakalık, soytarılık, şaklabanlık), tasdikçilik ve angaje olmak birlikte ele alınabilir. Dalkavukluk, şahsi menfaat ve yarar sağlamak, itibar kazanmak niyetiyle önemli ve mevki sahibi birine (yönetici, siyasiler) karşı abartılı ve sahte bir saygı ve hayranlık 
göstererek hoş görünme, yüzüne gülme, abartılı ve yersiz övgülerde bulunma, yaranma ve böylece onlar üzerinde etki sahibi olmayı amaçlama durumudur (Seyyar, 2004; Esmer ve Yüksel, 2019). Dalkavuk, yarar sağlamayı umduğu efendisi, herhangi biri ya da temsilcisi önünde eğilir, el-etek öper (Okutan, 2016), her zaman menfaatini ön planda tutar, hatta gün gelir eğilip el-etek öptüğü kişi gücünü kaybettiğinde, hemen yeni bir efendi edinir ve eski efendisinin aleyhinde bile atıp tutmaya başlar. Yağcı, yalaka, soytarı ve şaklaban gibi farklı isimlerle de bilinen bu kişilerin en mühim özellikleri riyakâr olmaları ve menfaat peşinde koşmalarıdır.

Dalkavukluk, örgüt içerisinde aranan, arzulanan bir davranış haline geldi ise kurumsal dalkavukluktan söz edilebilir. Kurumsal dalkavukluk, dalkavukluğun, bir işi yerine getirirken ki sürecin içine, hatta daha da beteri, kurumun ortak hafızası ve kültürüne taşınmasıdır. Hatta bazı örgütlerde kurumsal dalkavukluk öyle bir hal alır ki; iyi haberleri, sızdıran; kötü haberleri, dışlayan bir dalkavukluk kalkanı bile oluşur (Oğuz, 2019).

Dalkavukluğun bir çeşidi olarak değerlendirebileceğimiz tasdikçiler (evet efendimciler) ise yanında durdukları kişileri yanlış yönlendiren, her söylediğini onaylayan, yaranmaya çalıştıkları kişinin fikir ve tutumuna göre fikir ve tutumlarını belirleyen ve beyan eden kişilerdir. Bu kişiler, genel olarak itiraz bilmeyen, yumuşak başl1, suya sabuna dokunmayan ve etliye sütlüye karışmayan tiplerdir (Yeniçeri, 2011).

Sözle veya yazılı olarak bağlanan, bağımlı kişi anlamında kullanılan angaje teriminden hareketle başka birinin tutum ve davranışlarına bağlı olarak hareket eden çalışanları, angaje çalışanlar olarak nitelendirmek mümkündür. Bu tür çalışanlar da sığıntı şeklinde hareket ederler. Angaje çalışanlar, siyasiler, örnek alınan ya da etkili kişiler, yöneticiler gibi bir başkasına bağlanarak hareket eden ve davranışlarına yön veren çalışanlardır. Angaje çalışanlar, bir başkasının hükmü altına girme, tarafını tutma ve sözünden çıkmama, bir başkasına bağlı kalma, güdümlü olma gibi davranışlar sergilerler. Belirli gruplara ve kişilere angaje olan bu tip çalışanlar, angaje olduğu kişi ve grupların tutum ve davranışlarına göre konum alırlar, onların karşı oldukları görüşlere ise onlar da karşı olurlar.

Hazırcılık, yancılık ve bedavacılık gibi çalışan davranışları da bir tarafın yarar sağlarken diğer tarafın olumlu ya da olumsuz etkilenmediği sığıntılık şeklinde ortaya çıkan simbiyotik ilişkiler içerisinde sayılabilir. Emek harcamadan hazıra konmak, her şeyi çaba göstermeden elde etmeyi istemek, başkasının emeğiyle sunulan bir faydadan nemalanmak, bu türden çalışanların tipik özellikleridir. Başka çalışanların başarılarına yancılık yapmak, elde edilen kazanımlara bedavadan ortak olmak, her edinimini bedavadan sağlamaya çalışmak, beleşçilik, otlakçılık, emek sarf etmeden başkasının emeği üzerinden geçinmek hazırcı, yancı ve bedavacı çalışanlarda görülen diğer davranışlardır.

Diğer taraftan sığıntı çalışanların en büyük özelliklerinden birisi de beceriksiz, vasıfsız, aciz, özgüvensiz ve korkak olmalarıdır. Sığıntı çalışanlar, görev sorumluluğu ve ağırlığını kaldıramayacak kadar yeteneksiz, eksik ve aciz oldukları gibi sorumluluk alamayacak kadar da cesaretten yoksun kişilerdir. Tüm bunların yanında sığıntı çalışanlar; sorgulamayan, merak etmeyen, değişim ve yeniliği arzulamayan, inisiyatif almaktan kaçınan yapılarıyla da dikkat çekmektedirler. Yine sığıntı çalışanların girişken olmamak, çekingen, asosyal, sessiz ve içe kapanık olmak gibi tipik davranışları vardır.

\subsection{Asalaklar}

Taraflardan birinin (daha güçsüz ve küçük olanın) yarar sağlarken diğerinin (daha büyük ve güçlü olan tarafin) zarar gördüğü bir simbiyotik ilişki türü olan parasitizm, örgüt içerisinde ortaya çıan asalak çalışan tipleri ve davranışlarına benzetilebilir. Biyoloji biliminde "Bir canlıda sürekli veya geçici olarak yaşayarak ona zarar veren başka canlı, parazit." (TDK, 2020); mecazi olarak "Başkalarının sırtından geçinen (kimse), abacı, ekti, otlakçı, parazit, tufeyli." (TDK, 2020; Kubbealtı 
Lugatı, 2020) anlamlarına gelen asalaklar, konakların merhamet duygusunu sömürerek varlıklarını sürdürürler. Emek, haysiyet, alın teri gibi değerler onların dünyasında yer bulmaz. Onlar için önemli olan menfaat elde etmek ve ihtiyaçlarını gidermektir.

Örgütlerde görülen simbiyotik ilişki türleri olan asalaklar ile sığıntılar birbirine çok yakın özellikler gösterseler de aralarında nüanslar vardır. Asalakların, sığıntılardan en büyük farkları, bir başkasını sömürme ve onun sırtından geçinme özellikleridir. Oysa sığıntılarda, bir başkasının sofrasına (gölgesine) sığınma durumu söz konusudur.

Asalak (parazit) çalışan tiplerini daha iyi anlamak için örgüt içerisinde genel olarak ortaya çıkan dört çalışan tipinden söz etmek yararlı olacaktır: (1) Görev ve sorumluluğunu yerine getirenler, (2) Görev sorumluluğundan fazlasını yapanlar (özgeciler), (3) Üretkenlik karşıtı davranışlar sergileyenler ve (4) Başkası üzerinden geçinenler. Asalak çalışanlar, 4. gruba girmektedir.

Üretmeyip tüketmek, başkasının sırtından geçinmek, tembellik, sosyal ve sanal kaytarma, aylaklık, presenteizm, yan gelip yatma ve başkasını sömürme gibi davranışlar asalak çalışanların en bariz özellikleri arasında ifade edilebilir. Asalak çalışanlar, üretmeden sahip olmak güdüsüyle hareket ettikleri için amaçları ve menfaatlerini temin etmek için her türlü meşru ya da gayri meşru yola başvurabilirler. Almak istediklerini gönüllü alamıyorlarsa gönülsüz alma, çalma, hırsızlık yapma gibi her türlü gayri ahlaki yöntemi bile kullanabilirler.

Bu noktada, asalak insan tipi, sosyal aylaklık ve sosyal asalaklık kavramlarından bahsedilebilir. Asalak insan tipi, biyoloji biliminde tanımlanmış olan asalak canlılardan yola çıkarak başkaları üzerinden geçinen insanları belirtmek için türetilmiş bir yakıştırmadır. Bir örgütte bulunanların sayısı attıkça, kalabalığın arasında kaybolmanın kolaylığıyla bazı çalışanların sıvışıp saklanarak ait oldukları grup ya da takıma olan katkılarının ve performanslarının giderek azalması ise sosyal aylaklık emaresidir (Ürkmez, 2020). Bu durum, halat çekme yarışmasına katılan kişilerin, takım içinde ve tek başlarına iken çekme kuvveti incelenerek ispatlanmıştır. Halata daha fazla kişi eklendikçe takımın yarattığı toplam kuvvetin arttığı ancak takım üyelerinin uyguladığı bireysel kuvvetin azaldığı tespit edilmiştir. Takımı oluşturan kişilerin ortaya çıkardıkları bu durum, sosyal aylaklık olarak tanımlanmıştır.

Sosyal aylaklığın yerleştiği örgüt ortamında yeşeren bir diğer kavram olan sosyal asalaklık ise çalışmak ve üretmek yerine çalışan ve üretenleri takip eden ve seyreden, onların başarılarından nemalanan çalışan davranışlarını nitelendirmek için kullanılan bir kavramdır. Bu tür çalışanlar, çalışmak yerine başkasını, özellikle kendinden daha alt kademede olanları, çalıştırarak onların başarıları üzerinden başarılı olma ve başkasının başarılarını kendine mal etmeyi tercih ederler. Ancak ortaya çıkan en ufak hata ya da başarısızlıkta ise kendilerinde bir kusur görmeyerek kullandıkları çalışkan insanları suçlarlar.

Asalak çalışanların en meşhur özellikleri olan kaytarma, bazen sosyal kaytarma bazen de sanal kaytarma şeklinde ortaya çıkabilir. Sosyal aylaklığın bir başka ifadesi olarak da değerlendirilebilecek sosyal kaytarma, ortaklaşa çalışarak bir görevi başarmak için bir araya gelen ekibin içindeki kişilerden bazılarının emeklerini saklama eğimine girmesidir (Bellenger, 1999). Bu eğilimde olan takım üyesi, ortaklaşa çaba gösterdiği diğer üyelere göre gerek iş süreçlerinde gerekse motivasyon ve çabasında, azalan bir performans göstermektedir (Kanten, 2014). Sosyal kaytarma davranışı gösteren kişilerin, tembellikleri, daima sırtlarını bir başkasına dayamaları, başkasının emeği üzerinden geçinmeleri, görev ve sorumluklarını hakkıyla gerçekleştirmemeleri ve grup içerindeki bireysel çabalarının fark edilemeyeceğini düşünmeleri gibi bariz özellikleri vardır.

Sanal aylaklık olarak da ifade edilen sanal kaytarma ise çalışanların sosyal medya, bilgisayar ve internet teknolojilerini mesai/iş saatleri içerisinde gereksiz, eğlence veya bireysel amaçlı, iş diş1 kullanmaları ve suistimal etmeleridir (Henle ve Kedarnath, 2012; Örücü ve Yıldız, 2014). Sosyal medyada gezinmek, çevrimiçi yazışmak, mesaj/posta almak ya da göndermek, spor ya da haber sitelerine girmek, internet alışverişi yapmak, müzik dinlemek, film izlemek, kumar oynamak, 
yetişkin, blog ya da form sitelerine girmek, banka işlemleri yapmak gibi şahsi amaçlı yapılan davranışlar, sanal kaytarma davranışları içerisinde değerlendirilebilir (Blanchard ve Henle, 2008).

Diğer taraftan asalak çalışanlar, sürekli kaytarma psikolojisi içerisinde olduklarından kafaları hep başka yerdedir. Burada presenteizm kavramına vurgu yapmak gerekir. Kendini işe verememe (Çoşkun, 2012), işte var olamama (Baysal, 2012) sorunu olarak ifade edilebilecek presenteizm, çalışanların fiziksel ya da ruhsal olarak kendilerini iyi hissetmedikleri için (Çoban, 2015) verimsiz, ilgisiz çalışmalarıdır. Diğer taraftan sanal kaytarmada olduğu gibi çalışanların internette gezinmek, TV İzlemek, oyun oynamak, mesai arkadaşlarıyla lüzumsuz iletişim kurmak ve dedikodu yapmak gibi davranışlarla görev dışında harcadıkları zaman da presenteizm içerisinde değerlendirilmektedir (Özmen, 2011).

Asalak çalışanlar, üretmeyip tüketen, çalışanlar üzerinden geçinen özellikleriyle tanınırlar. Bazen bankamatik memuru olarak bazen de hayalet çalışan olarak karşımıza çıkabilirler. İşe gitmeden ya da sadece birkaç gün giderek, hiçbir iş yapmadan ya da çok az bir iş yaparak aybaşında hak etmediği maaşı alan, arada bir gözüken, hatta varlığı diğer çalışanlar tarafında hiç bilinmeyen, hayalet gibi kalabalığın içinde fark edilmeden çalışan, çalışıyormuş gibi gözüken ancak verimli olmayan çalışanlar, özellikle kamu kurumlarında varlığına çokça rastlanan bankamatik memuru ya da hayalet çalışan davranışlarına örnek verilebilir.

Asalak çalışanlar, yan gelip yatmaları, tembellikleri, bir başkasının emeği ve üretkenliğine sülük gibi yapışıp sömürmeleri ve emek hırsızlığı yapmalarıyla da bilinirler. Üretmeyip tükettikleri ve bir başkasının emeğini sömürdükleri için sürekli bir bahaneleri vardır. İş yapmadıkları gibi bu kabahatlerini örtmek için sürekli mızmızlanır ve söylenirler. Dedikodu, gevezelik ve laf kalabalığı yapmak gibi alışkanlıkları vardır. İlgisiz, tasasız, aldırmaz ve umursamaz olmak, asalak çalışan tiplerin diğer özellikleri arasında sayılabilir. Asalaklar, ayrıca herhangi bir sorumluluk altına girmeyen seyirci tiplerdir. Bu kişiler bazen lakayt ve dalgacı tavırlarıyla asalaklıklarını bastırmaya çalışırlar. Asalak çalışanların bu tür davranışlar sergileyerek ulaşmak istedikleri hedef ise asalak çalışanların ortak özelliklerinden birisi olan kişisel menfaatlerine ulaşmaktır.

Örgütlerde simbiyotik ilişki içerinde olan bu üç tür çalışan tipi ve davranışlarını Şekil 1'deki gibi özetlemek mümkündür. 


\begin{tabular}{|c|c|c|}
\hline \multicolumn{3}{|c|}{ Örgütlerde Simbiyotik Yaşam/İlişkiler } \\
\hline$\stackrel{\text { İşbirlikçiler }}{\downarrow}$ & $\underset{\downarrow}{\text { Siğıntılar }}$ & $\underset{\downarrow}{\text { Assalaklar }}$ \\
\hline - Sinerji oluşturanlar & - Dalkavuklar & - Sosyal asalaklar \\
\hline - Takım oyuncuları & - Tasdikçiler & - Sosyal aylaklar \\
\hline - Kyosei oluşturanlar & - Angaje çalişanlar & - Sosyal kaytarıcılar \\
\hline - Yardımlaşanlar & - Hazırcılar & - Sanal kaytarıcilar \\
\hline - Paylaşanlar & - Yancilar & - Kafası başka yerde olanlar \\
\hline - Dayanışanlar & - Bedavacilar & - Emek hırsızları \\
\hline - Anlaşanlar & - Beceriksizler & - Bankamatik memurları \\
\hline - Uzlaşanlar & - Yağcilar & - Hayalet çalışanlar \\
\hline & - Yalakalar & - Tembeller \\
\hline & - Soytarılar & - Seyirciler \\
\hline & - Şaklabanlar & - Üretmeyip tüketenler \\
\hline & - Özgüvensizler & - Başkasının emeğini sömürenler \\
\hline & - Korkaklar & - Bahaneciler \\
\hline
\end{tabular}

Şekil 1: Örgütlerde Simbiyotik Yaşam/İlişkiler

\section{SONUÇ}

Doğada karşılıklı yarar elde etmek için birlikte hareket eden canlılar olduğu gibi örgütlerde de bu tür bireylere rastlamak mümkündür. Nasıl ki doğada, hayatta kalmak ve çıkar sağlamak için birliktelik ve ortaklık yapan canlılar var ise örgütlerde de rekabetçi üstünlük elde etmek, devamlılığını sağlamak, çeşitli zorlukların üstesinden gelmek, menfaat ve çıkar elde etmek amacıyla simbiyotik ilişkiler geliştiren çalışanlar söz konusudur.

Bu çalışmada, biyolojik menşeli simbiyoz ve simbiyotik ilişki kavramlarından yola çıkılarak örgütlerde de karşılıklı çıkar ilişkisi kuran, sürekliliği sağlama, menfaat ve çıkar amacı güden simbiyotik ilişkilerin bulunduğuna dair bir incelemede bulunulmuştur. Böylece "Örgütlerde simbiyotik yaşam (ilişki)" kavramı ortaya atılmıştır. Bu kapsamda örgütlerde simbiyotik ilişki içerisinde olan üç tip ilişki ve çalışan davranışı tanımlanmıştır: İşbirlikçiler, sığıntılar ve asalaklar.

Iş̧birlikçiler, eksikliklerinin bilincinde olarak tek başlarına üstesinden gelemeyecekleri işler için sinerji, ekip çalışması, ortaklık, ittifak, yardımlaşma, anlaşma, bağdaşma, uzlaşma, dayanışma gibi yolları kullanarak güç birliği yapan ve çıkar ortaklığı kuran çalışan türüdür. Sı̆̆ııtılar, beceriksiz, özgüvensiz, aciz ve yetersiz olduklarını ve bir başkası olmadan varlık gösteremeyeceklerini bildiklerinden bedavacılığı, beleşçiliği, yancılığı, bir başkasına dalkavukluğu, yalakalığı, yağcılığı, şaklabanlığı, evet efendimciliği, hazırcılığ Asalaklar ise sosyal aylaklık, sanal kaytarma, kalabalığın içinde kaybolma, tembellik, seyirci olmak, emek hırsızlığı, başkasının çabasını sömürme gibi stratejilerle bir başkasının sırtından geçinerek örgütsel yaşamlarını sürdürmeye çalışan tiplerdir. 


\section{KAYNAKÇA}

Alıç, M. (1995). Örgütler. Kuram ve Uygulamada Eğitim Yönetimi Dergisi, 1(1), 1-40. https://dergipark.org.tr/tr/pub/kuey/issue/10394/127183

Barner, R. (1994). Enablement: The key to empowerment. Training and Development, 48(6), 33-37. https://go.gale.com/ps/anonymous?id=GALE\%7CA16074720\&sid=googleScholar\&v=2.1\&it $=\mathrm{r} \&$ linkaccess $=\mathrm{abs} \& \mathrm{issn}=10559760 \& \mathrm{p}=\mathrm{AONE} \& \mathrm{sw}=\mathrm{W}$

Bayraktar, L. (2014). Ortak yaşama kültürü ve felsefesi. Bizim Külliye Dergisi, 16(62), 48-50. http://bizimkulliye.com/

Baysal, İ. A. (2012). Presenteeism (işste varolmama sorunu) ile örgütsel bağlllık arasındaki ilişki: Adnan Menderes Üniversitesi akademik personeli üzerinde bir uygulama (Yayımlanmamış Yüksek Lisans Tezi). Adnan Menderes Üniversitesi Sosyal Bilimler Enstitüsü. Aydın.

Bellenger, B. L. (1999). A constructive-developmental examination of the propensity to engage in social loafing (Degree of Doctor of Philosophy). Graduate Faculty of Alabama. USA.

Blanchard, A.L. ve Henle, C. A. (2008). Correlates of different forms of cyberloafing: the role of norms and external locus of control. Computers in Human Behavior, 24(3), 1067-1084. doi:10.1016/j.chb.2007.03.008

Coşkun, Ö. (2012). İki işyerinde işe devamsızlık ve kendini işe verememede etkili faktörlerin değerlendirilmesi (Yayımlanmamış Yüksek Lisans Tezi). Ankara Üniversitesi Sağlık Bilimleri Enstitüsü. Ankara.

Çoban, Ö. (2015). Örgütlerde presenteeism sorunu. Küçükalan D., Tükeltürk, Ş. A. \& Gürkan, G. Ç. (Ed.), Örgütsel davranışta güncel konular içinde (s. 15-33). İstanbul. Detay Yayıncılık.

Çolakoğlu, M. (2019). Organizasyonları yönetmek "simbiyoz yönetim". Harvard Business Review Türkiye. https://hbrturkiye.com/blog/simbiyoz-yonetim (ET:10.12.2020).

Doğan, S. (1996). Yeni bir yönetim anlayışı olarak kyosei. Verimlilik Dergisi, 3, 35-52. https://dergipark.org.tr/tr/pub/verimlilik

Donnolen, A. (1998). Takım dili. İstanbul. Sistem Yayınc1lık.

Esmer, Y. ve Yüksel, M. (2019). Örgütsel dalkavukluk. Uluslararası Sosyal Araştırmalar Dergisi, 12(67), 895-900. http://dx.doi.org/10.17719/jisr.2019.3777

Genç, Z. (2017). Otel işletmeleri çalışanlarının psikolojik güçlendirme ve mentorluk ihtiyaçları. IJSES-International Journal of Social and Economic Sciences, 7(1), 91-97. http://ijses.org/index.php/ijses/article/view/210

Hardy, C., Phillips, N. ve Lawrence, T. B. (2003). Resources, knowledge and influence: The organizational effects of interorganizational collaboration. Journal of Management Studies, 2(40), 321-347. https://doi.org/10.1111/1467-6486.00342

Henle, C. A. ve Kedarnath, U. (2012). Cyberloafing in the workplace. Zheng, Y. (Ed.). Encyclopedia of cyber behavior içinde (s. 560-573). USA. IGI Global.

Kanten, P. (2014). İşyeri nezaketsizliğinin sosyal kaytarma davranışı ve işten ayrılma niyetine üzerindeki etkisinde duygusal tükenmenin aracılık rolü. Aksaray Üniversitesi İ̈BF Dergisi, 6(1), 11-26. http://aksarayiibd.aksaray.edu.tr/tr/download/article-file/209409

Keeton, W. T., ve Gould J. L. (2003). Biological science. Demirsoy, A., Türkan, İ. \& Gündüz, E. (Çev. Ed.). Ankara. Palme Yayıncılık.

Köksal, O. (2011). Organizasyonel etkinliği sağlamanın yeni yolu: Simbiyotik liderlik. C. Ü. İktisadi ve İdari Bilimler Dergisi, 12(1), 55-72. http://acikerisim.ohu.edu.tr/xmlui/handle/11480/2709

Kubbealt1 Lugat1. (2020). http://lugatim.com/ (ET:10.12.2020).

Lai, L. S. L. (2000). A Synergistic Approach to Information Systems Project. https://www.researchgate.net/publication/2911955_A_Synergistic_Approach_to_Information _Systems_Project(ET:22.02.2021).

Nişanyan, S. (2000). Nişanyan Sözlük: Çăgdaş Türkçenin Etimolojisi. https://www.nisanyansozluk.com/? (ET:22.02.2021). 
Oğuz, Ş. (2019). Kurumsal Dalkavukluk Envanterinizi Çıkardınız mı?. http://www.bilimevi.com.tr/ Makas_Dergisi_Subat_Mart_2019_6.Sayi,ktp-227 (ET:22.02.2021).

Okutan, E. (2016). Osmanlı'da dalkavukluk. https://bilimvegelecek.com.tr/index.php/2015/01/01/ osmanlidadalkavukluk/ (ET:15.11.2021).

Örücü, E. ve Yıldız, H. (2014). İşyerinde kişisel internet ve teknoloji kullanımı: Sanal kaytarma. Ege Akademik Baklş, 14(1), 99-114. https://dergipark.org.tr/en/download/article-file/560040

Özmen, G. (2011). Presenteizm ile örgütsel bağlllık ilişkisi: Tekstil çalışanları üzerine bir araştırma (Yayımlanmamış Yüksek Lisans Tezi). Osmangazi Üniversitesi Sosyal Bilimler Enstitüsü. Eskiş̧ehir.

Özyiğitoğlu, G. (2017). Türkçe liken terminolojisi için yeni öneriler. Avrasya Terim Dergisi, 5(2), 14-18. https://dergipark.org.tr/tr/pub/ejatd/issue/37231/429695

Robbins, S. P. ve Judge, T. A. (2009). Organizational behavior. USA. Pearson.

Seyyar, A. (2004). Sosyal siyaset terimleri. İstanbul. Beta Yayıncılık.

Smith, R. M. (1997). Defining leadership through followership: concepts for approaching leadership development. 83. Ulusal İletişim Birliği Kongresi. Chicago.

TDK (Türk Dil Kurumu). (2020). https://sozluk.gov.tr/ (ET:10.12.2020).

Torun, Y. (2016). Personel güçlendirme ve işsen ayrllma niyeti ilişkisinde örgütsel sinizmin aracılık rolü: Örgütsel sinizm ölçeği geliştirmeye yönelik bir araştırma (Yayımlanmamış Doktora Tezi). Marmara Üniversitesi Sosyal Bilimleri Enstitüsü. İstanbul.

TÜBA (Türkiye Bilimler Akademisi). (2020). http://www.tubaterim.gov.tr/ATS/index.php/w_ anasayfa/search $/ \mathrm{q}=$ ortakya $\% \mathrm{C} 5 \% 9$ Fam\&arama_options $=2 \&$ szl $=23 \% 2 \mathrm{C} 32 \& \operatorname{lng}=1 \% 2 \mathrm{C} 2 \% 2$ C3 (ET:01.12.2020).

Ünal, S. (2017). Farklı Kültürel Kimliklerle Birlikte Yaşamanın Koşulları: Ortak Bir Sosyal Hayat Mümkün Mü?. Proceedings Book of 2nd International Scientific Researches Congress on Humanities and Social Sciences (IBAD-2017). April 20-23. İstanbul.

Ürkmez, İ. (2020). Sosyal aylaklık ve sosyal asalaklık. http://www.peryod.com.tr/ (ET:20.12.2020).

Yeşilmen, H. (2019). Birlikte yaşama tecrübesine ve ortak yaşam alanına işaret eden kavramsal bir çalışma: Ebrulî kültür (Mardin örneği). Mukaddime Dergisi, 10(1), 77-97. 10.19059/mukaddime.445624

Zaccaro, S. J. ve Horn, Z. N. J. (2003). Leadership theory and practice: Fostering an effective symbiosis. The Leadership Quarterly, 14, 769-806.

Zeyrek, F. Y. (2020). Mikroplar ve konak adaptasyonu: Savaşamıyorsan anlaş. https://www.klimud.org/public/uploads/dosya/1352560396.pdf. (ET:12.12.2020).

Yeniçeri, Ö. (2011). Konformizm, yozlaşma ve itaatsizlik. Journal of Economy Culture and Society, 44, 69-90. https://dergipark.org.tr/tr/pub/iusoskon/issue/9548/119253 